LAPORAN KASUS

\title{
Priapismus Intraoperatif pada Hemoroidektomi dan URS dengan Anestesi Spinal
}

\section{Intraoperative Priapism in a Patient during Haemorrhoidectomy and URS under Spinal Anesthesia}

\author{
Refni Riyanto*, Doso Sutiyono*, Jati Listiyanto Pujo* \\ *Bagian Anestesiologi dan Terapi Intensif FK Undip/ RSUP dr. Kariadi, Semarang
}

\begin{abstract}
Background: Intraoperative priapism is a very rare condition, but requires serious attention and rapid management. Therapy must be directed to empty the cavernous body to avoid viscosity and sludging that will result in irreversible damage to the venous system
\end{abstract}

Case: A man of 35 years was admitted to operating room with a diagnosis of right uretrolithiasis and haemorhoid to perform longo haemorhoidectomy and URS procedure. Using the technique of spinal anesthesia, with $27 G$ needle number. Local anesthetic was Hyperbaric bupivacaine $15 \mathrm{mg}$. At the time of the preparation of URS drapping, penis were erect. GA did not solve the problem hence epinephrine $0.1 \mathrm{mg}$ intra corpus cavernous were injected. The penis then detumescenced, and surgery resumed. Procedures completed within 1 hour. Postoperatively the patient returns to the ward.

Keyword: Intraoperative priapism, spinal anesthesia

\section{ABSTRAK}

Latar belakang: Priapismus intraoperatif jarang dijumpai, tetapi memerlukan perhatian serius dan segera. Terapi harus dimulai dengan cepat untuk meningkatkan drainase dari vena pada korpus kavernosus sehingga tidak terjadi viskositas dan sludging, yang dapat mengakibatkan kerusakan ireversibel dari berbagai rute dari aliran balik vena.

Kasus: Seorang laki-laki 35 tahun dengan diagnosis curiga batu ureter dan hemoroid eksterna dijadwalkan untuk operasi Longo hemorhoidektomi dan URS. Digunakan teknik anestesi spinal dengan jarum spinal $27 G$ dan obat anestesi lokal bupivacaine hiperbarik 0,5\% $15 \mathrm{mg}$. Pada saat persiapan URS diketahui penis ereksi. GA tidak dapat mengatasi masalah sehingga dilakukan injeksi epinephrine $0.1 \mathrm{mg}$ intra corpus cavernous. Penis mengalami detumesensi, kemudian operasi dilanjutkan. Operasi berlangsung selama 1 jam. Postoperatif pasien kembali ke bangsal.

Kata kunci: Priapismus intraoperatif, anestesi spinal 


\section{PENDAHULUAN}

Priapismus perioperatif dilaporkan terjadi pada $2,4 \%$ pasien yang menjalani operasi. Kejadian ini bervariasi sesuai usia, $8 \%$ pada pasien $<50$ tahun dan $0,9 \%$ pada pasien yang lebih tua.Secara umum insiden hampir sama antara anestesi umum (3,5\%) maupun epidural $(3,8 \%)$, tetapi kejadiannya rendah $(0,3 \%)$ pada anestesi spinal. ${ }^{2}$

Dampak yang ditimbulkan karena priapismus intraoperatif menyebabkan waktu operasi menjadi lambat bahkan dapat mengalami penundaan. Hal ini terutama terjadi pada operasi urologi, dimana priapismus dapat menyebabkan scope endoskopi tidak dapat diinsersikan.

Priapismus adalah kondisi penis ereksi menetap selama lebih dari 4-6 jam, tanpa didahului oleh obsesi birahi dan rangsangan seksual. Priapismus dapat dibagi menjadi dua kategori, yakni primer (idiopatik) dan sekunder. Priapismus primer merupakan akibat rangsangan fisik maupun psikis yang tidak berhubungan dengan penyakit ataupun kondisi yang dapat menyebabkan atau memperlama ereksi. Priapismus sekunder merupakan akibat berbagai faktor yang secara langsung maupun tidak langsung mempengaruhi reaktifitas ereksi penis. ${ }^{1}$

Priapismus intraoperatif dalam anestesi termasuk dalam priapismus primer, biasanya terjadi pada saat persiapan, pemasangan kateter foley atau tindakan transurethral. Durasi ereksi dibawah anestesi biasanya terjadi lebih singkat dibandingkan dengan priapismus tipe lain.

\section{KASUS}

Seorang laki-laki, 33 tahun dengan berat badan $75 \mathrm{~kg}$ datang dengan keluhan timbul benjolan di dubur yang nyeri dan kadang berdarah selama 4 bulan. Pasien juga mengeluhkan nyeri pinggang kanan yang hilang timbul, kemudian diperiksakan dan didiagnosis terdapat batu di ureter kanan. Pada pemeriksaan fisik saat datang didapatkan Keadaan umum baik, $\mathrm{TD}=110 / 80 \mathrm{mmHg}, \mathrm{HR}=$ $76 \mathrm{x} / \mathrm{mnt}, \mathrm{RR}=14 \mathrm{x} / \mathrm{mnt}$ dan afebris. Didapatkan benjolan pada dubur pada arah jam 7, dan jam 9 dengan kesan hemorrhoid eksterna. Pada pinggang didapatkan nyeri ketok costovertebral. Pemeriksaan laboratorium preoperatif menunjukkan kadar hemoglobin 15.5 $\mathrm{mg} / \mathrm{dl}$, hitung lekosit $10.500 / \mathrm{mm}^{3}$, Trombosit $424.000 / \mathrm{mm}^{3}$, Ureum 18,7 $\mathrm{mg} / \mathrm{dl}$, kreatinin $1,2 \mathrm{mg} / \mathrm{dl}$, dan kadar elektrolit normal. Pasien direncanakan untuk dilakukan operasi bersama oleh bagian bedah digestif dan bedah urologi, dan dijadwalkan untuk longo hemoroidektomi sebagai terapi untuk hemmorhoid dan urethral retrograde sistoskopi untuk menegakkan diagnosis kausatif obstruksi saluran kencing.

Pasien dikonsulkan ke bagian anestesi 
dan dilakukan kunjungan preoperatif. Pada anamnesis tidak didapatkan riwayat alergi obat dan makanan. Riwayat tekanan darah tinggi, asma, riwayat operasi, gangguan perdarahan disangkal. pemeriksaan fisik menunjukkan kondisi pasien baik, tanpa gangguan sistemik dan pasien disetujui untuk pembiusan dengan status fisik ASA I.

Premedikasi dilakukan di kamar operasi dengan midazolam $4 \mathrm{mg}$, Fentanyl 50 mcg, dan granisetron $1 \mathrm{mg}$. Induksi anestesi dengan teknik anestesi spinal, menggunakan jarum $27 \mathrm{G}$, dan bupivacaine hiperbarik 0,5\% (Marcaine Heavy $^{\mathbf{M}}$ ) $15 \mathrm{mg}$

Pada menit ke-3 onset tercapai blokade sensorik setinggi dermatom T10. Dilakukan operasi longo hemoroidektomi dalam posisi litotomi selama 30 menit. Durante operasi tidak didapatkan gejolak kardiovaskuler yang berarti. Operasi dilanjutkan dengan ureteroretrosistoskopi (URS) dalam posisi yang sama. Pada saat drapping untuk persiapan URS penis mengalami ereksi . Pasien tidak merasakan keluhan apapun. Diputuskan untuk dilakukan GA dengan ketamin. Penis tidak mengalami detumesensi secara nyata sehingga dilakukan injeksi epinefrin 0,1 mg intra korpus kavernosus. Penis kemudian mengalami detumesensi, operasi dilanjutkan, scope sistoskopi bisa dimasukkan tanpa kesulitan. Operasi URS selesai dalam 1 jam. Pasca operasi pasien kembali ke ruangan.

\section{PEMBAHASAN}

Mekanisme pasti priapismus belum sepenuhnya diketahui, akan tetapi diduga merupakan hasil dari kombinasi yang komplek meliputi faktor psikologis, neuroendokrin, dan jaringan vaskuler. Inervasi parasimpatis penis berasal dari medulla spinalis segmen sakral (S2-S4) melalui nervi erigentes. Pada saat penis flaksid, aktivitas simpatetik meningkatkan tonus otot intrinsik pada arteriole sehingga menurunkan aliran darah ke korpus kavernosus. Pada saat yang sama, venula yang menerima aliran drainase dari corpus kavernosus selalu terbuka. Pada saat akan timbul ereksi (intumesensi), impuls parasimpatis melebarkan arteriol sehingga aliran darah yang menuju korpus kavernosus meningkat. Secara bersamaan terjadi penutupan aliran vena. Bila siklus ini berbalik, maka penis menjadi lemas kembali (detumesensi). Mekanisme ereksi penis adalah fenomena yang sangat kompleks. Dalam keadaan lembek, arteriol yang sebagian ditutup, sedangkan venula dan saluran arteriovenosa tetap terbuka, memberikan drainase tanpa hambatan dari arteri inflow. Setiap rangsangan refleksogenik atau psikogenik akan menghasilkan stimulasi arus keluar parasimpatis sakral, menyebabkan relaksasi dari arteriol dan penutupan sebagian dari venula dan shunt arteriovenosa dengan pembengkakan berikutnya dari corpora menyebabkan ereksi. Efek dari sistem saraf simpatik dan parasimpatik pada organ seksual pria adalah saling 
melengkapi. Aktivasi reseptor adrenergik alpha-1 menghasilkan ejakulasi sementara aktivasi jenis reseptor kolinergik M3 menghasilkan ereksi. Biasanya ereksi reda setelah penyempitan arteriolar simpatik dimediasi dengan pengurangan inflow dan peningkatan drainase vena.

Mediator vasoaktif meliputi nitrit oksida, vasopressin dan bradikinin juga mempengaruhi kondisi ereksi.

Priapismus dapat didefinisikan sebagai ereksi penis terus-menerus tanpa berhubungan dengan eksitasi seksual, yang bila dibiarkan tidak dikelola selama lebih dari empat jam akan menghasilkan edema, risiko abrasi, pengeringan jaringan dan nekrosis penis. Penyebab priapismus dapat bersifat primer, sekunder atau idiopatik. Priapismus dengan etiologi primer tidak disertai dengan gangguan tubuh, mungkin karena faktor fisik atau psikologis. Priapismus sekunder disebabkan oleh faktor langsung atau tidak langsung mempengaruhi ereksi, misalnya anemia sel sabit, polisitemia, leukemia dan koagulopati; traumatis dan pembedahan, misalnya sumsum tulang belakang cedera, trauma penis atau trauma panggul/ perineum, misalnya neoplastik metastasis, myeloma, kanker prostat atau kanker penis; neurologis misalnya herniasi diskus lumbal, multiple sclerosis atau tumor sumsum tulang belakang, misalnya infeksi prostatis, uretritis, sifilis, malaria atau diabetes mellitus, atau farmakologis misalnya verapamil, nitrogliserin, heparin, haloperidol, prazosine. Priapismus merupakan akibat dari kegagalan mekanisme detumescensi, antara lain: blockade drainase venula, pelepasan neurotransmitter yang berlebihan, paralisis mekanisme detumesensi intrinsik, relaksasi otot polos intrakavernosa yang memanjang. Darah yang terus terkumpul pada anyaman kavernosa menyebabkan ereksi memanjang. Bila kondisi menetap hingga 6 jam menyebabkan rasa nyeri. ${ }^{2}$

Pada kasus ini, ereksi belum terjadi selama lebih dari 4 jam, tetapi penulis mengkhawatirkan kemungkinan terjadinya priapismus, karena ereksi terjadi tanpa didahului oleh obsesi birahi dan rangsangan seksual. Selain itu, kondisi ini tidak memungkinkan bagi ahli bedah untuk memasukkan alat sistoskopi.

Priapismus pada anestesi spinal dan epidural adalah refleksogenik, terutama jika blokade simpatik meluas di atas permukaan mid-torakal atau bisa juga kedua refleksogenik dan psikogenik. Rangsangan refleksogenik ini timbul karena stimulasi dari saraf pudenda (S2, $3,4)$ dengan instrumentasi sebelum timbulnya blokade sensorik lengkap. Penjelasan lain yang mungkin adalah blokade lengkap segmen sakral dari sumsum tulang belakang tulang belakang selama anestesia. Meskipun mungkin psikogenik sebagai hasil dari sensasi pendengaran yang berlebihan selama plana anestesi kedua.

Berbagai penelitian telah memberikan 
Tabel 1. Obat-obatan yang sering dipakai untuk mengatasi ereksi penis intraoperasi ${ }^{1}$

\begin{tabular}{|c|c|c|c|c|c|}
\hline Obat & farmakologi & Rute & Efek lain & & Dosis \\
\hline fenilefrin & Agonis alfa-1 & intrakorporeal & Inotrop+, MAP>, & & $100-500 \mathrm{mcg}$ \\
\hline epinefrin & Agonis alfa-1 & intrakorporeal & inotrop & & $10-20 \mathrm{mcg}$ \\
\hline Ketamin & disosiatif & i.v & halusinasi & & $0,5-1 \mathrm{mg} / \mathrm{kg}$ \\
\hline amilnitrat & $\begin{array}{l}\text { Relaksan otot } \\
\text { polos }\end{array}$ & inhalasi & Komplikasi elderly & & $0,3 \mathrm{ml}$ \\
\hline terbutalin & Agonis beta & po, sc, iv & $\begin{array}{l}\text { Takikardi, edem } \\
\text { hipoK }^{+}\end{array}$ & paru, & $\begin{array}{l}5 \mathrm{mg} \text { po, } \\
0,25-0,5 \mathrm{sc} / \mathrm{iv}\end{array}$ \\
\hline $\begin{array}{l}\mathrm{NE} \text {, metaraminol, } \\
\text { dll }\end{array}$ & Agonis alfa & Intrakorporeal, iv & $\begin{array}{l}\text { Hipertensi, PE, } \\
\text { aneurisma }\end{array}$ & rupture Incase & \\
\hline
\end{tabular}

pilihan pengobatan untuk priapismus intraoperatif. Metode tersebut antara lain dengan memperdalam anestesi umum dengan induksi hipotensi simultan, blok saraf, relaksasi, aspirasi korpus kavernosus dengan atau tanpa prosedur shunting dan pemberian ketamin. Induksi hipotensi dengan natrium nitroprusside atau mendalamkan anestesi umum dapat mengakibatkan penurunan tekanan darah arteri. Pada pasien dengan usia lanjut atau penyakit arteri koroner hal ini dapat memicu kegawatan jantung. Injeksi $8 \mathrm{ml}$ bupivakain $0,25 \% \mathrm{ke}$ dalam spatium subpubic untuk memblok n.dorsalis penis diketahui efektif. Ketamin juga sering digunakan untuk mengobati priapismus, memiliki sifat merelaksasi penis dan juga efek disosiatif pada sistem limbik.

Terdapat beberapa modalitas terapi untuk mengatasi penis ereksi. Saat ereksi timbul, setiap stimulasi di daerah genital harus dihentikan meliputi preparasi operasi, manipulasi uretra, dan pemasangan kateter foley, harus segera dihentikan. Bila sistoskopi sudah terpasang, bila memungkinkan harus segera dilepaskan. Jika ereksi terjadi pada saat anestesi "dangkal", maka tingkatan anestesi harus didalamkan. Pada anestesi spinal atau epidural, harus dipastikan terjadi blokade segmen sacral.

Bila pengelolaan konservatif gagal mengatasi ereksi, diperlukan intervensi lain. Penyemprotan ethyl chloride pada penis atau blok penile dapat digunakan untuk menghambat input sensoris, sehingga diharapkan memutuskan jalur reflek sakral.

Obat-obatan lain juga pernah dilaporkan untuk mengatasi priapismus.

Ketamin merupakan obat anestesi disosiatif, diberikan intravena dengan dosis $0,5-1,8 \mathrm{mg} / \mathrm{kg}$, berdasarkan asumsi 
bahwa ereksi terjadi sebagai respon terhadap rangsangan eksternal. Sedangkan, efek disosiasi obat ini menghambat terhadap sistem limbik. Ketamin juga dapat membantu relaksasi penis dengan cara menurunkan "central vagal outflow", menghambat re-uptake norepinefrin pada neuroeffector junction pada jaringan erektil kavernosa, atau menghambat transmisi yang melalui ganglia parasimpatis. Penggunaan ketamin harus hati-hati pada pasien dengan usia tua dan penyakit kardiovaskuler.

Pada kasus ini, setelah diketahui bahwa terjadi ereksi penis, dilakukan anestesi umum dengan ketamin $1 \mathrm{mg} / \mathrm{kg}$, namun penis tidak mengalami detumesensi.

Injeksi Intracorporeal dengan vasopressor direkomendasikan oleh beberapa peneliti. Detumesensi terjadi dengan cepat pada semua pasien dengan injeksi tersebut. Agen ini menghasilkan detumesensi dengan mengurangi suplai darah ke corpora cavernosa atau meningkatkan drainase darah dari corpora cavernosa melalui aktivasi reseptor adrenergik. Fenilefrin, merupakan agonis alfa-1 murni, diberikan intrakavernosa dalam dosis 100-200 mcg. Angka keberhasilan tindakan ini dilaporkan 100\% dalam 2-3 menit. Aktifitas Alfa-1 murni tidak memiliki efek yang merugikan jantung seperti krisis hipertensi atau edema paru. Hal ini membuat fenilefrin lebih aman bila dibandingkan dengan epinefrin, norepinephine, metaraminol yang memiliki efek tambahan terhdap beta-1, sehingga memiliki dampak ke kardiovaskuler. Meskipun tindakan ini dikaitkan dengan peningkatan MAP, tetapi tidak ada gejolak kardivaskuler yang terjadi sehubungan dengan penggunaan obat ini. Laporan lain menyebutkan injeksi metaraminol intrakavernosa dengan dosis $10-25 \mathrm{mcg}$ menimbulkan detumesensi tanpa gejolak kardiovaskuler. Meski demikian, penggunaan obat obatan seperti metaraminol, norepinefrin, dan epinefrin harus diperhatikan karena obat-obat tersebut setidaknya memiliki aktivitas beta-1 yang dapat mempengaruhi aktivitas kardiovaskuler.

Agonis beta 2 adrenoreseptor, misalnya Terbutalin 0,2 -0,5 mg, intravena dapat dipergunakan untuk mengatasi priapismus intraoperatif. Mekanisme kerja obat ini belum jelas, tetapi diduga bahwa terbutalin merelaksasi otot-otot polos di korpus kavernosus yang teregang, sehingga memperlancar aliran darah yang meninggalkan penis. Penggunaan terbutalin harus diperhatikan pada pasien dengan penyakit jantung koroner yang nyata karena obat ini dapat menyebabkan takikardia, edema pulmo atau hipokalemia. Diperkirakan untuk mengendurkan otot polos seluruh corpora cavernosa mengakibatkan keadaan normal dari penis dan relaksasi seluruh tunika albugenia, sehingga meningkatkan aliran darah pada venula dan saluran arterovenosa dan menghasilkan detumesensi.

Golongan obat lainnya yaitu 
antikolinergik. Mekanisme kerjanya melalui penghambatan asetilkolin pada system nitritoksida. Glikopirolat lebih dipilih dibandingkan atropin sulfat maupun skopolamin karena efek takikardia dan gangguan saraf pusatnya lebih kecil. Penggunaan glikopirolat menjadi pilihan yang aman dan dapat digunakan pada pasien dengan penyakit arteri koroner atau bila status kardiovaskuler tidak stabil.

Aspirasi dengan jarum suntik nonheparin ke dasar salah satu corpora cavernosa memiliki tingkat keberhasilan sekitar 30\%. Bila gagal, dapat dilakukan tindakan pembedahan. Tujuan dari tindakan bedah adalah membuat shunt antara corpus cavernosum dan glans penis, korpus spongiosum atau vena sehingga mekanisme oklusi vena dapat ter-bypass.

Meskipun penatalaksanaan secara farmakologis telah dikenal secara luas, penatalaksanaan bedah masih dipergunakan jika pengobatan secara konservatif gagal. Berbagai prosedur bedah dipergunakan dalam mengatasi masalah tersebut, antara lain Grayhack shunt (anatomosis antara corpus cavernosum dan vena saphena, Ligasi proximal arteri pundenda interna, Winter shunt (cavernous spongiosum shunt), Cavernosus dorsal veint shunt, insisi, Irigasi dan drainase sinus corporeal, Aspirasi perkutan, korpus cavernosum, atau amputasi penis jika berhubungan dengan penyakit keganasan genitalia. ${ }^{7}$

\section{RINGKASAN}

Priapismus intraoperatif jarang dijumpai, tetapi memerlukan perhatian serius dan segera. Terapi harus segera dilakukan untuk meningkatkan drainase dari vena pada korpus kavernosus sehingga tidak terjadi viskositas dan sludging, yang dapat mengakibatkan kerusakan ireversibel dari berbagai rute dari aliran balik vena. Berbagai modalitas obat dapat digunakan untuk mengatasi priapismus intraoperatif. Pada kasus ini, kami melaporkan kasus priapismus intraoperatif yang berhasil ditangani setelah injeksi adrenalin intrakavernosa.

\section{DAFTAR PUSTAKA}

1. Baltogiannis DM, Charalabopoulos AK, Giannakopoulos XK, Giannakis DJ, Sofikitis NV. Penile Erection During Transurethral Surgery. Journal of Andrology, Vol. 27, No. 3 2006: 376-80

2. Monk TG, Intraoperative Penile Erection. In: Atlee JL (editor) Complication In Anesthesia $2^{\text {nd }}$ edition. Philadelphia: Elsevier Saunders 2007: 840-2

3. Natarajan P, Remadevi R., Rao PB, Ramachandran TR. Priapism following spinal anesthesia in urological procedures. Anaesth Pain \& Intensive Care 2012;16(1):47-50

4. Valley M, Sang CN. Use of Glycopyrrolate to treat intraoperative penile erection. Regional Anesth 1994; 19: 423-8

5. Van ArsdelenKN, Chen JW, Vernon Smith MJ. Penile erections complicating transurethral surgery. J urol 1983; 129: 374-6

6. Harme MR, Harmon EP, Kirkpatrick DV, Stern MJ, Humbert J R. Priapism as complication of sickle cell disease. J urol 1991; 145: 1-5

7. C. Van Der Horst, Henrik Stuebinger, Christoph Seif, Diethild Melchior, F.J. Martínez-Portillo, K.P. Juenemann. Priapism - Etiology, Pathophysiology And Management. Journal of the Brazilian Society of Urology 2003; 29(5): 391-400 